\title{
Analysis of Intonation Patterns of Selected Nigerian Bilingual Educated Speakers of English
}

\author{
Emmanuela U. Asadu ${ }^{1}$, Faith A. Okoro ${ }^{1} \&$ Goodluck C. Kadiri ${ }^{1}$ \\ ${ }^{1}$ Department of English and Literary Studies, University of Nigeria, Nigeria \\ Correspondence: Goodluck C. Kadiri, Department of English and Literary Studies, University of Nigeria, \\ Nigeria.
}

Received: April 5, 2019 Accepted: May 6, 2019 Online Published: May 8, 2019

doi: 10.5539/elt.v12n6p45 URL: https://doi.org/10.5539/elt.v12n6p45

\begin{abstract}
The intelligibility of everyday speech is built on the mastery and the use of appropriate intonation patterns. This makes intonation the music of everyday speech of which its appropriate use has been the final hurdle that the majority of the speakers of English as a Second Language have not crossed. This paper investigated the intonation patterns of the randomly selected 45 bilingual educated speakers of English, from diverse educational backgrounds representing the three senatorial zones in Ebonyi State. A paragraph from Roach (2010) was given to the participants to read. It was recorded and converted to WAVE audio with the use of audio converter. The utterances of interest to the research were extracted with the use of Sony Sound Forge and segmented on a text grid window on Praat. Pierrehumbert's Auto-segmental Metrical approach to intonation served as the theoretical framework and the transcription was done using ToBI. The study revealed a low level of proficiency in the use and assignment of accurate patterns of intonation in the speeches of the participants. Aside the widely known and commonly used intonation patterns of fall, rise, rise-fall and fall-rise, it was observed that there was the presence of the use of low pitch accent, low boundary tone in the speeches of the participants. Significant inclination towards the use of the falling tone was observed. However, bilingual make-up or educational qualification does not determine appropriate use of intonation patterns. In a bid to, therefore, account for effective communication among educated bilingual speakers of English, more time should be given to the development of this skill using meaningful utterances in context rather than the use of words or sentences in isolation.
\end{abstract}

Keywords: bilingualism, English as a second language, English speakers, intonation patterns, Pierrehumbert's auto-segmental metrical approach

\section{Introduction}

The English language is one language that is spoken all over the world, including Nigeria where it serves official purposes. As a result, it has been extolled so high among its speakers in Nigeria; yet, it is unfortunate that its use among its educated speakers has never been without prevalent errors. This, to a very large extent, has led to a level of unintelligibility in the speeches of the speakers of English as a Second Language (ESL) leading to an ineffective communication as the message among interlocutors are misunderstood. It goes with saying that the level of intelligibility of every speech is dependent on the mastery of the pronunciation of words that make up the speech of which to a very large extent; appropriate assignment of the specific patterns of intonation has become a serious challenge to the speakers of ESL. Intonation brings melody to all languages and it is something that one probably does not think about when speaking ones native language. It is the rise and fall of the voice while speaking, little wonder Suciu (2016) sees it as the music of everyday speech. It is worthy to note that Nigeria being a multilingual nation had over four hundred indigenous languages of which in one way or the other, these languages compete with one another and equally affect the use of English. These languages in contact, according to Weinreich (1968) have birthed bilingualism as a result of interference. The use of English in the everyday lives of the educated bilingual cannot be over emphasized because of the place of English in Nigeria but what becomes questionable is the level of effective communication among its users. The goal of the study is not to have the bilingual speakers of English in Ebonyi State speak the way native speakers do, but to approximate towards proficiency, fluency and good communicative competence and performance. This becomes necessary because in the words of Akindele, (2015), speaking English without the approximate stress and 
intonation tunes is like speaking most Nigerian languages which are tonal with wrong tone which in turn leads to breakdown in communication. This study, therefore, investigated the patterns of intonation in the utterances of selected bilingual educated speakers of English in Ebonyi State.

\subsection{Literature Review}

Intonation being the music of everyday speech, notwithstanding, it remains that one aspect of the suprasegmentals that has not received adequate attention when compared to the amount of attention received by the segmental features of English. This has been a matter of great concern to researchers as the little attention given has not amounted to any reasonable level of good performances. It is, therefore, not in doubt that it was in this vein that Banjo (1979) contended that the appropriate use of English intonation is the final hurdle which vast majority of speakers of English as a Second Language has not managed to cross. Examining why, in spite of the important roles that intonation plays in the expression of attitudes in the English utterances, the status and significance of intonation in Nigerian schools and colleges have consistently and persistently been at the lowest ebb of academic concern, Ibrahim and Faleke (2013) investigated patterns of intonation tunes in the marking of attitudes in Nigerian English. It was observed that the use of tunes in Nigerian English was low; where the differences lie minimally in the utterances with falling pitch and appear significantly with the rising tone. Akinjobi and Oladipupo (2010) also looked at the place of intonation as not only being that which is said but how it is said, investigating the intonation and attitude in Nigerian English with the intention of ascertaining the extent to which Nigerian speakers of English use English intonation tunes to express attitudes. A level of deficiency in the use of intonation was recorded among the respondents. It was observed that despite the use of intonation in their communication, a level of competence in appropriate assignment of tunes was in lack. This, however, confirms the saying that complex intonation tunes are put into restricted use among the speakers of English in Nigeria (Okon, 2001). In the same vein, Sunday (2010) sought to describe the suprasegmentals in the speeches of twenty Yoruba - English bilingual adult aphasics who were patients at the University College, Ibadan and observed that at the level of intonation, there was a complete absence of attitudinal use of intonation in the speeches and a predominance of the falling tone as well as that of the rising tone.

There is, therefore, no gain saying the fact that at various spheres of life, there is a recurrent decline in the appropriate use and assignment of intonation patterns to words that make up the speeches of interlocutors, irrespective of professions and this is a cry cum call for attention among researchers in a bid to ensure effective communication. There is every need that an adequate attention be given to this aspect of suprasegmentals called intonation like its segmentals counterparts. To a very large extent, this has to be traced to the foundational laying stage, taking bearings from the secondary schools so that exposure to higher levels of education would have definite effects as it translates to the everyday speech of those who have been accredited to possess some academic competence by the award of first degree.

\section{Methodology}

The population of the study comprised of sixty participants from the three senatorial zones in Ebonyi State who have attained a certain level of exposure to education. They were randomly selected using the stratified random sampling technique method and the major yardstick for stratification was the level of education in which the participants have been exposed to, irrespective of the career. They were required to speak for some minutes, guided by some extracts from Roach (2010) and the melody of their utterances were listened to and recorded. The recorded utterances were converted to WAVE audio with the use of an audio converter after which they were constantly played, listened to and analysed both perceptually and acoustically. The utterances containing the tones of interest of the researcher were extracted through the use of Sony Sound Forge. Pitch extraction software, praat, was used for the analysis of the utterances and for displaying the utterances which were transcribed through the use of Tone and Break Indices (ToBI). It is worthy to note that a set of symbols has been provided by ToBI for the transcription of intonation phenomena and the following among others were identified at the course of the study. Thus:

$\mathrm{H}^{*}$ : high pitch accent

$\mathrm{L}^{*}$ : low pitch accent

$\mathrm{L}+\mathrm{H}^{*}$ : bitonal pitch accent with low tone followed by high tone prominence

$\mathrm{L}^{*}+\mathrm{H}$ : bitonal pitch accent with low tone prominence followed by high tone

$\mathrm{H}^{*}+\mathrm{L}$ : bitonal pitch accent with high tone prominence followed by low tone

! $\mathrm{H}^{*}$ : down-stepped high pitch accent

$\mathrm{L}+! \mathrm{H}^{*}$ : bitonal pitch accent with low tone followed by a down-stepped high tone prominence 
$\mathrm{L}^{*+}+\mathrm{H}$ : bitonal pitch accent with low tone prominence followed by down-stepped high

tone

$\mathrm{H}+\mathrm{H}^{*}$ : bitonal pitch accent with high tone followed by down-stepped high prominence

$\mathrm{H}^{*}+\mathrm{H}$ : bitonal pitch accent with high tone prominence followed by a down-stepped high tone.

L-L\%: low phrase accent, low boundary tone

It is worthy to note that this tone and break indices (ToBI) was used to bring to limelight the theory, Autosegmental Metrical Approach to intonation, which was adopted in the study. According to the basic principle of Auto-segmental Metrical approach, intonation is phonologically represented as a string of low (L) and high $(\mathrm{H})$ tones and combinations thereof. The identity as Hs and Ls is largely determined by phonetic observation and defined in relative terms. " $\mathrm{H}$ " represents tones deemed to be high in a melody with respect to the speakers range and other tones in the same contour while " $\mathrm{L}$ " is used to represent tones deemed to be low by the same criteria.

Suffice it to say that Pierrehumbert's intonational phonology is in some ways the extension of Pike's (1945) theory which used a system of four tones numbered 1-4. With the use of a system of diacritics which distinguish tones located on accented syllables from those occurring at boundaries and between accents, Pierrehumbert reduced the description into High $(\mathrm{H})$ and Low $(\mathrm{L})$, positing two kinds of tones which include pitch accents (high or low) and boundary tones. The pitch accent can either be single or doubled, and it has starred (*) tones which implies the tone that is directly associated with the accented syllable. Double tone accents have an additional tone and referred to as a floating tone which is marked with a dash (-).

A bio-data form was used to gather information on the socio-cultural profile of the participants. It is worthy to note that among the sixty participants, it was observed that three participants who were willing to identify with the study were still undergraduates and were not yet in final year, either. Three other participants further declined from lending their voices for recording due to the recurrent social insecurity all over the country. About nine participants who were willing to be part of the study observed that their Local Government Areas had been covered by the researchers as each Local Government Area had a maximum of five slots. Therefore, a total of forty-five participants responded positively to the study.

\subsection{Socio-cultural Profile of Participants}

The table below contains the participants' age category, sex, educational qualification, occupation, course studied/studying (as in the cases of degree in view) and additional languages spoken with English. The table further shows that the participants are bilinguals and educated, from diverse fields of study. The percentages were got based on the general number of frequency (45) of each variable.

Table 1. Group breakdown

\begin{tabular}{llll}
\hline $\mathrm{S} / \mathrm{N}$ & Variable & Frequency & Percentage \\
\hline 1 & Age category & & \\
& $21-30$ & 28 & $62 \%$ \\
& $31-40$ & 13 & $29 \%$ \\
& $41-50$ & 3 & $7 \%$ \\
& 51 and above & 1 & $2 \%$ \\
& Total & 45 & \\
& Sex & & \\
& Male & 31 & $69 \%$ \\
& Female & 14 & $31 \%$ \\
& Education qualification & & \\
& PhD & 1 & $2 \%$ \\
& PhD in view & 2 & $4 \%$ \\
& Masters & 3 & $7 \%$ \\
\hline
\end{tabular}




\begin{tabular}{|c|c|c|c|}
\hline & Masters in view & 17 & $38 \%$ \\
\hline & Bachelors & 22 & $49 \%$ \\
\hline \multirow[t]{10}{*}{4} & Occupation & & \\
\hline & Students & 16 & $36 \%$ \\
\hline & Public servants & 6 & $13 \%$ \\
\hline & Civil servants & 10 & $22 \%$ \\
\hline & Farmer & 1 & $2 \%$ \\
\hline & Clergy & 1 & $2 \%$ \\
\hline & Legal practitioners & 2 & $4 \%$ \\
\hline & Teachers & 5 & $11 \%$ \\
\hline & Business & 1 & $2 \%$ \\
\hline & Applicants & 3 & $7 \%$ \\
\hline \multirow[t]{4}{*}{5} & Institutional Category & & \\
\hline & University & 45 & $100 \%$ \\
\hline & College of Education & - & - \\
\hline & Polytechnic & - & - \\
\hline \multirow[t]{2}{*}{6} & Additional Language Spoken with English & & \\
\hline & Igbo & 45 & $100 \%$ \\
\hline \multirow[t]{24}{*}{7} & Courses of Study & & \\
\hline & Mass communication & 2 & $4 \%$ \\
\hline & Electrical/ Electronic Engineering & 2 & $4 \%$ \\
\hline & Human Resource Management & 1 & $2 \%$ \\
\hline & Business Education & 2 & $4 \%$ \\
\hline & Public Admin & 3 & $7 \%$ \\
\hline & Marketing & 1 & $2 \%$ \\
\hline & Home Economics Education & 1 & $2 \%$ \\
\hline & Religion And Philosophy & 1 & $2 \%$ \\
\hline & English \& Literary Studies & 4 & $9 \%$ \\
\hline & Economics & 2 & $4 \%$ \\
\hline & Law & 2 & $4 \%$ \\
\hline & Accountancy & 2 & $4 \%$ \\
\hline & Linguistics & 2 & $4 \%$ \\
\hline & Agric Engineering & 1 & $2 \%$ \\
\hline & Maths \& Statistics & 2 & $4 \%$ \\
\hline & Psychology & 4 & $9 \%$ \\
\hline & Theology & 1 & 25 \\
\hline & Agric Science & 1 & $2 \%$ \\
\hline & Edu. Admin. and Planning & 1 & $2 \%$ \\
\hline & Medical Microbiology & 1 & $2 \%$ \\
\hline & Food \& Nutrition & 1 & $2 \%$ \\
\hline & Medical \& Human Anatomy & 1 & $2 \%$ \\
\hline & Applied Physics & 1 & $2 \%$ \\
\hline
\end{tabular}




$\begin{array}{lll}\text { Science Laboratory Technology } & 1 & 2 \% \\ \text { Sociology \& Anthropology } & 1 & 2 \% \\ \text { Nursing } & 1 & 2 \% \\ \text { Human Kinetics \& Health Edu. } & 1 & 2 \% \\ \text { Medival \& Laboratory Science } & 1 & 2 \% \\ \text { Unspecified } & 1 & 2 \%\end{array}$

Table 1 above shows the age categories of the participants who were part of the research. The percentage(s) show that the allocation of the bio-data form to various participants in different senatorial zones was in no way influenced by any form of biasness. It is, therefore, a true reflection of the researchers' impartiality in the distribution of the form. On the sex, however, $69 \%$ of the participants were male while $31 \%$ of females participated in the study. It is worthy to note that the research was not gender biased neither was the bio-data form shared with biased mind. It was rather as a result of the availability and willingness of the participants. Different degrees and levels of education were also covered as there were $49 \%$ of Bachelor degree holders, $38 \%$ Masters in view, 7\% Master's degree holders, $4 \% \mathrm{PhD}$ in View and 2\% PhD holders. This, therefore, implies that the study was not limited to a certain degree of education apart from those who are yet to have their first degree. The occupation of the participants further reveals that different spheres of life, within the reach of the researchers, were represented. Also, it was observed that the participants had different courses of study which in a way implies that a level of perfection in their use and appropriate assignment of intonation patterns may not be realized.

It is worthy to note that the $100 \%$ of the university attendance by the participants was coincidental. There was no level of biasness associated with its selection as the researchers were open to having graduates from different categories of institution as participants. More so, the bilingual make-up of the participants was only English and Igbo. While there were $100 \%$ of bilingual speakers of English and Igbo. It is, therefore, not in doubt that all the participants were educated bilinguals.

\section{Results and Discussion}

\subsection{Performance of Participants in Intonation}

Table 2. Participants' performance in intonation

\begin{tabular}{|c|c|c|c|c|c|c|c|c|c|}
\hline 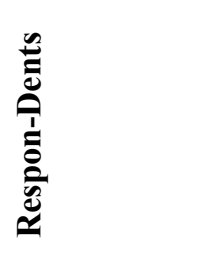 & 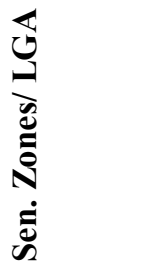 & 齐 & 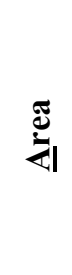 & $\stackrel{0}{:}$ & Uूँ & ङ્ద & $\vec{E}$ & $\begin{array}{l}\frac{\lambda}{\mathscr{a}} \\
\frac{0}{\partial} \\
\frac{\partial}{0} \\
\frac{0}{0}\end{array}$ & 를 \\
\hline CONTROL & & $\mathbf{L}^{*}$ & $\mathbf{H}^{*}$ & $\mathbf{L}^{*}$ & $\mathbf{L}^{*+\mathbf{H}}$ & $\mathbf{H}^{*}$ & $\mathbf{L}^{*+\mathbf{H}}$ & $\mathbf{H}^{*}+\mathbf{L}$ & $\mathbf{L}^{*+\mathbf{H}}$ \\
\hline \multicolumn{10}{|l|}{ Ebonyi North } \\
\hline 1 & Abakaliki & $\mathrm{L}^{*}$ & $\mathrm{H}^{*}$ & $\mathrm{~L}^{*}$ & $\mathrm{~L}^{*}$ & $\mathrm{H}^{*+\mathrm{L}}$ & $\mathrm{H}^{*+\mathrm{L}}$ & L-L\% & $\mathrm{L}^{*}$ \\
\hline 2 & Ebonyi & $\mathrm{H}^{*}$ & $\mathrm{H}^{*}$ & $\mathrm{H}^{*}$ & $\mathrm{H}^{*}$ & $\mathrm{~L}^{*}$ & $\mathrm{H}^{*+\mathrm{L}}$ & $\mathrm{H}^{*+\mathrm{L}}$ & $\mathrm{L}^{*+\mathrm{H}}$ \\
\hline 3 & Ebonyi & $\mathrm{L}^{*}$ & $\mathrm{H}^{*}$ & $\mathrm{~L}^{*}$ & $\mathrm{~L}^{*}$ & $\mathrm{~L}^{*+\mathrm{H}}$ & $\mathrm{L}^{*+\mathrm{H}}$ & L-L\% & $\mathrm{L}^{*}$ \\
\hline 4 & Ohaukwu & $\mathrm{L}^{*}$ & $\mathrm{H}^{*}$ & $\mathrm{H}^{*}$ & $\mathrm{H}^{*+\mathrm{L}}$ & $\mathrm{L}^{*}$ & $\mathrm{~L}^{*}$ & $\mathrm{~L}^{*+\mathrm{H}}$ & $\mathrm{H}^{*+\mathrm{L}}$ \\
\hline 5 & Ohaukwu & $\mathrm{H}^{*}$ & $\mathrm{H}^{*}$ & $\mathrm{~L}^{*}$ & $\mathrm{H}^{*+\mathrm{L}}$ & $\mathrm{L}^{*+\mathrm{H}}$ & $\mathrm{H}^{*+\mathrm{L}}$ & $\mathrm{L}^{*}+\mathrm{H}$ & $\mathrm{L}^{*}$ \\
\hline 6 & Ohaukwu & $\mathrm{L}^{*}$ & $\mathrm{~L}^{*}$ & $\mathrm{~L}^{*}$ & $\mathrm{~L}^{*+\mathrm{H}}$ & $\mathrm{L}^{*}$ & $\mathrm{~L}^{*}$ & L-L\% & $\mathrm{L}^{*}$ \\
\hline 7 & Ohaukwu & $\mathrm{L}^{*}$ & $\mathrm{H}^{*}$ & $\mathrm{H}^{*}$ & $\mathrm{~L}^{*+\mathrm{H}}$ & $\mathrm{L}^{*}$ & $\mathrm{~L}^{*}$ & $\mathrm{H}^{*+\mathrm{L}}$ & $\mathrm{L}^{*}$ \\
\hline 8 & Ohaukwu & $\mathrm{L}^{*}$ & $\mathrm{H}^{*}$ & $\mathrm{~L}^{*}$ & $\mathrm{~L}^{*}$ & $\mathrm{H}^{*+\mathrm{L}}$ & $\mathrm{L}^{*+\mathrm{H}}$ & $\mathrm{H}^{*+\mathrm{L}}$ & $\mathrm{L}^{*}$ \\
\hline 9 & Izzi & $\mathrm{H}^{*}$ & $\mathrm{H}^{*}$ & $\mathrm{~L}^{*}$ & $\mathrm{~L}^{*}$ & $\mathrm{~L}^{*}$ & $\mathrm{H}^{*+\mathrm{L}}$ & $\mathrm{H}^{*+\mathrm{L}}$ & $\mathrm{L}^{*}$ \\
\hline
\end{tabular}




\begin{tabular}{|c|c|c|c|c|c|c|c|c|c|}
\hline 10 & Izzi & $\mathrm{H}^{*}$ & $\mathrm{H}^{*}$ & $\mathrm{~L}^{*}$ & $\mathrm{~L}^{*}$ & $\mathrm{~L}^{*}$ & $\mathrm{~L}^{*}$ & L-L\% & $\mathrm{H}^{*+\mathrm{L}}$ \\
\hline 11 & Izzi & $\mathrm{H}^{*}$ & $\mathrm{H}^{*}$ & $L^{*}$ & $\mathrm{~L}^{*+\mathrm{H}}$ & $L^{*}$ & $\mathrm{~L}^{*}$ & $\mathrm{H}^{*+\mathrm{L}}$ & $L^{*}$ \\
\hline 12 & Izzi & $\mathrm{H}^{*}$ & $\mathrm{H}^{*}$ & $\mathrm{H}^{*}$ & $\mathrm{~L}^{*+\mathrm{H}}$ & $\mathrm{L}^{*}$ & $\mathrm{H}^{*+\mathrm{L}}$ & $\mathrm{H}^{*+\mathrm{L}}$ & $\mathrm{H}^{*+\mathrm{L}}$ \\
\hline \multicolumn{10}{|c|}{ Ebonyi Central } \\
\hline 13 & Ikwo & $\mathrm{L}^{*}$ & $\mathrm{~L}^{*}$ & $\mathrm{~L}^{*}$ & $\mathrm{~L}^{*+\mathrm{H}}$ & $\mathrm{H}^{*}$ & $\mathrm{H}^{*+\mathrm{L}}$ & $\mathrm{L}^{*+\mathrm{H}}$ & $\mathrm{H}^{*+\mathrm{L}}$ \\
\hline 14 & Ikwo & $\mathrm{H}^{*}$ & $\mathrm{H}^{*}$ & $\mathrm{H}^{*}$ & $\mathrm{H}^{*}+\mathrm{L}$ & $L^{*}$ & $\mathrm{H}^{*+\mathrm{L}}$ & $\mathrm{H}^{*+\mathrm{L}}$ & $L^{*}$ \\
\hline 15 & Ikwo & $\mathrm{H}^{*}$ & $\mathrm{~L}^{*+\mathrm{H}}$ & $\mathrm{H}^{*+\mathrm{L}}$ & $\mathrm{L}^{*}$ & $L^{*}$ & $\mathrm{H}^{*+\mathrm{L}}$ & $\mathrm{H}^{*+\mathrm{L}}$ & $\mathrm{L}^{*+\mathrm{H}}$ \\
\hline 16 & Ikwo & $\mathrm{L}^{*}$ & $\mathrm{H}^{*}$ & $\mathrm{~L}^{*}$ & $\mathrm{~L}^{*}$ & $\mathrm{H}^{*+\mathrm{L}}$ & $\mathrm{H}^{*+\mathrm{L}}$ & $\mathrm{H}^{*+\mathrm{L}}$ & $\mathrm{H}^{*+\mathrm{L}}$ \\
\hline 17 & Ikwo & $\mathrm{H}^{*}$ & $\mathrm{~L}^{*}$ & $\mathrm{~L}^{*}$ & $\mathrm{~L}^{*}$ & $\mathrm{~L}^{*}$ & $\mathrm{~L}^{*}$ & $\mathrm{~L}^{*}+\mathrm{H}$ & $\mathrm{L}^{*}$ \\
\hline 18 & Ishielu & $L^{*}$ & $\mathrm{H}^{*}$ & $\mathrm{H}^{*}$ & $\mathrm{H}^{*}+\mathrm{L}$ & $\mathrm{H}^{*}$ & $\mathrm{~L}^{*+\mathrm{H}}$ & L-L\% & $\mathrm{L}^{*+\mathrm{H}}$ \\
\hline 19 & Ishielu & $\mathrm{L}^{*}$ & $\mathrm{~L}^{*}$ & $L^{*}$ & $\mathrm{~L}^{*+\mathrm{H}}$ & $L^{*}$ & $\mathrm{~L}^{*+\mathrm{H}}$ & $\mathrm{L}^{*}+\mathrm{H}$ & $L^{*}$ \\
\hline 20 & Ishielu & $\mathrm{L}^{*}$ & $\mathrm{H}^{*}$ & $\mathrm{H}^{*}$ & $\mathrm{H}^{*}+\mathrm{L}$ & $\mathrm{L}^{*}$ & $\mathrm{H}^{*+\mathrm{L}}$ & $\mathrm{L}^{*+\mathrm{H}}$ & $\mathrm{L}^{*}$ \\
\hline 21 & Ezza North & - & - & - & - & - & - & - & - \\
\hline 22 & Ezza South & $\mathrm{H}^{*}$ & $\mathrm{~L}^{*}$ & $\mathrm{H}^{*}$ & $\mathrm{~L}^{*+\mathrm{H}}$ & $\mathrm{L}^{*}$ & $\mathrm{~L}^{*+\mathrm{H}}$ & $\mathrm{L}^{*+\mathrm{H}}$ & $\mathrm{L}^{*+\mathrm{H}}$ \\
\hline 23 & Ezza South & $\mathrm{H}^{*}$ & $\mathrm{~L}^{*}$ & $\mathrm{H}^{*}$ & $\mathrm{H}^{*}+\mathrm{L}$ & $\mathrm{H}^{*}$ & $\mathrm{H}^{*+\mathrm{L}}$ & L-L\% & $\mathrm{H}^{*+} \mathrm{L}$ \\
\hline 24 & Ezza South & $\mathrm{L}^{*}$ & $\mathrm{~L}^{*}$ & $\mathrm{~L}^{*}$ & $\mathrm{~L}^{*}$ & $\mathrm{H}^{*+\mathrm{L}}$ & $\mathrm{H}^{*+\mathrm{L}}$ & $\mathrm{H} *+\mathrm{L}$ & $\mathrm{L}^{*}$ \\
\hline 25 & Ezza South & $\mathrm{L}^{*}$ & $\mathrm{H}^{*}$ & $\mathrm{H}^{*}$ & $\mathrm{~L}^{*}$ & $\mathrm{~L}^{*}$ & $\mathrm{H}^{*+\mathrm{L}}$ & $\mathrm{H}^{*+\mathrm{L}}$ & $\mathrm{L}^{*}$ \\
\hline
\end{tabular}

Ebonyi South

\begin{tabular}{|c|c|c|c|c|c|c|c|c|c|}
\hline 26 & Afikpo North & $\mathrm{L}^{*}$ & $\mathrm{~L}^{*}$ & $\mathrm{H}^{*}$ & $\mathrm{~L}^{*+\mathrm{H}}$ & $\mathrm{L}^{*+\mathrm{H}}$ & $\mathrm{L}^{*}$ & $\mathrm{H}^{*+\mathrm{L}}$ & $\mathrm{L}^{*}$ \\
\hline 27 & Afikpo North & $\mathrm{L}^{*}$ & $\mathrm{~L}^{*}$ & $\mathrm{~L}^{*}$ & $\mathrm{~L}^{*+\mathrm{H}}$ & $\mathrm{L}^{*}$ & $\mathrm{~L}^{*}$ & $\mathrm{H}^{*+\mathrm{L}}$ & $\mathrm{H}^{*+\mathrm{L}}$ \\
\hline 28 & Afikpo North & $\mathrm{H}^{*}$ & $\mathrm{H}^{*}$ & $\mathrm{H}^{*}$ & $\mathrm{~L}^{*}$ & $\mathrm{~L}^{*}$ & $\mathrm{H}^{*}+\mathrm{L}$ & $\mathrm{H}^{*+\mathrm{L}}$ & $\mathrm{H}^{*+\mathrm{L}}$ \\
\hline 29 & Afikpo North & $\mathrm{L}^{*}$ & $\mathrm{H}^{*}$ & $\mathrm{~L}^{*}$ & $\mathrm{H}^{*+\mathrm{L}}$ & $\mathrm{H}^{*+\mathrm{L}}$ & $\mathrm{H}^{*+\mathrm{L}}$ & $\mathrm{H}^{*+\mathrm{L}}$ & $\mathrm{L}^{*+\mathrm{H}}$ \\
\hline 30 & Afikpo North & $\mathrm{L}^{*}$ & $\mathrm{H}^{*}$ & $\mathrm{~L}^{*}$ & $\mathrm{~L}^{*}$ & $\mathrm{H}^{*+\mathrm{L}}$ & $\mathrm{L}^{*+\mathrm{H}}$ & $\mathrm{H}^{*+\mathrm{L}}$ & $\mathrm{H}^{*+\mathrm{L}}$ \\
\hline 31 & Afikpo South & $\mathrm{H}^{*}$ & $\mathrm{H}^{*}$ & $\mathrm{~L}^{*}$ & $\mathrm{~L}^{*}$ & $\mathrm{~L}^{*+\mathrm{H}}$ & $\mathrm{L}^{*+\mathrm{H}}$ & L-L \% & $\mathrm{L}^{*+\mathrm{H}}$ \\
\hline 32 & Afikpo South & $\mathrm{L}^{*}$ & $\mathrm{H}^{*}$ & $\mathrm{~L}^{*}$ & $\mathrm{~L}^{*}$ & $\mathrm{H}^{*+\mathrm{L}}$ & $\mathrm{H}^{*+\mathrm{L}}$ & L-L \% & $\mathrm{L}^{*+\mathrm{H}}$ \\
\hline 33 & Afikpo South & $\mathrm{L}^{*}$ & $\mathrm{H}^{*}$ & $\mathrm{H}^{*}$ & $\mathrm{H} *+\mathrm{L}$ & $\mathrm{H}^{*}$ & $\mathrm{H}^{*}+\mathrm{L}$ & $\mathrm{H}^{*+\mathrm{L}}$ & $\mathrm{L}^{*}$ \\
\hline 34 & Afikpo South & $\mathrm{L}^{*}$ & $\mathrm{H}^{*}$ & $\mathrm{~L}^{*}$ & $\mathrm{~L}^{*}$ & $\mathrm{H}^{*}$ & $\mathrm{H}^{*+\mathrm{L}}$ & L-L\% & $\mathrm{L}^{*+\mathrm{H}}$ \\
\hline 35 & Afikpo South & $\mathrm{H}^{*}$ & $\mathrm{H}^{*}$ & $\mathrm{H}^{*+\mathrm{L}}$ & $\mathrm{L}^{*}$ & $\mathrm{H}^{*+\mathrm{L}}$ & $\mathrm{L}^{*+\mathrm{H}}$ & $\mathrm{L}^{*+\mathrm{H}}$ & $\mathrm{L}^{*}$ \\
\hline 36 & Ivo & $\mathrm{H}^{*}$ & $\mathrm{H}^{*}$ & $\mathrm{~L}^{*}$ & $\mathrm{~L}^{*}$ & $\mathrm{H}^{*+\mathrm{L}}$ & $\mathrm{L}^{*}$ & $\mathrm{~L}^{*+\mathrm{H}}$ & $\mathrm{L}^{*+\mathrm{H}}$ \\
\hline 37 & Ivo & $\mathrm{L}^{*}$ & $\mathrm{H}^{*}$ & $\mathrm{~L}^{*}$ & $\mathrm{~L}^{*}$ & $\mathrm{~L}^{*}$ & $\mathrm{H}^{*}+\mathrm{L}$ & $\mathrm{L}^{*+\mathrm{H}}$ & $\mathrm{L}^{*}$ \\
\hline 38 & Ohaozara & $\mathrm{L}^{*}$ & $\mathrm{H}^{*}$ & $\mathrm{~L}^{*+\mathrm{H}}$ & $\mathrm{H}^{*+} \mathrm{L}$ & $\mathrm{L}^{*}$ & $\mathrm{~L}^{*+\mathrm{H}}$ & $\mathrm{H}^{*+\mathrm{L}}$ & $\mathrm{L}^{*}$ \\
\hline 39 & Ohaozara & $\mathrm{L}^{*}$ & $\mathrm{H}^{*}$ & $\mathrm{H}^{*+\mathrm{L}}$ & $\mathrm{L}^{*}$ & $\mathrm{~L}^{*+\mathrm{H}}$ & $\mathrm{L}^{*+\mathrm{H}}$ & L-L\% & $\mathrm{L}^{*}$ \\
\hline 40 & Ohaozara & $\mathrm{L}^{*}$ & $\mathrm{~L}^{*}$ & $\mathrm{H}^{*+\mathrm{L}}$ & $\mathrm{L}^{*+\mathrm{H}}$ & $\mathrm{L}^{*+\mathrm{H}}$ & $\mathrm{L}^{*+\mathrm{H}}$ & $\mathrm{H}^{*+\mathrm{L}}$ & $\mathrm{L}^{*}$ \\
\hline 41 & Ohaozara & $\mathrm{L}^{*}$ & $\mathrm{H}^{*}$ & $\mathrm{H}^{*+\mathrm{L}}$ & $\mathrm{L}^{*+\mathrm{H}}$ & $\mathrm{L}^{*+\mathrm{H}}$ & $\mathrm{L}^{*+\mathrm{H}}$ & $\mathrm{L}^{*+\mathrm{H}}$ & $\mathrm{L}^{*+\mathrm{H}}$ \\
\hline 42 & Onicha & $\mathrm{L}^{*}$ & $\mathrm{H}^{*}$ & $\mathrm{H}^{*+\mathrm{L}}$ & $\mathrm{H}^{*+\mathrm{L}}$ & $\mathrm{H}^{*}$ & $\mathrm{H}^{*}+\mathrm{L}$ & $\mathrm{H}^{*+\mathrm{L}}$ & $\mathrm{H}^{*+} \mathrm{L}$ \\
\hline 43 & Onicha & $\mathrm{L}^{*}$ & $\mathrm{~L}^{*}$ & $\mathrm{H}^{*+\mathrm{L}}$ & $\mathrm{L}^{*}$ & $\mathrm{H}^{*+\mathrm{L}}$ & $\mathrm{H}^{*+\mathrm{L}}$ & L-L\% & $\mathrm{L}^{*+\mathrm{H}}$ \\
\hline 44 & Onicha & $\mathrm{H}^{*}$ & $\mathrm{~L}^{*}$ & $\mathrm{~L}^{*}$ & $\mathrm{~L}^{*}+\mathrm{H}$ & $\mathrm{L}^{*+\mathrm{H}}$ & $\mathrm{H}^{*+\mathrm{L}}$ & $\mathrm{H}^{*+\mathrm{L}}$ & $\mathrm{L}^{*+\mathrm{H}}$ \\
\hline 45 & Onicha & $\mathrm{L}^{*}$ & $\mathrm{H}^{*}$ & $\mathrm{~L}^{*}$ & $\mathrm{H}^{*+\mathrm{L}}$ & $\mathrm{L}^{*+\mathrm{H}}$ & $\mathrm{H}^{*+\mathrm{L}}$ & L-L\% & $\mathrm{L}^{*+\mathrm{H}}$ \\
\hline 46 & Onicha & $\mathrm{L}^{*}$ & $\mathrm{H}^{*}$ & $\mathrm{H}^{*+\mathrm{L}}$ & $\mathrm{L}^{*}$ & $\mathrm{~L}^{*}$ & $\mathrm{H}^{*+\mathrm{L}}$ & L-L\% & $\mathrm{H}^{*+\mathrm{L}}$ \\
\hline
\end{tabular}

The performance of participants in intonation, as shown in Table 2, reveals that some participants could not realize the appropriate intonation patterns of the utterances properly. It further reveals that aside the widely known and commonly used intonation patterns of fall, rise, fall-rise and rise-fall, another pattern of intonation 
which was obtainable was the low pitch accent, low boundary tone 'L-L\%'. With further reference to the Auto-segmental Metrical Phonology, about five (5) intonation patterns were observed to be predominant in the speech of the selected bilingual educated speakers of English in Ebonyi State. Nonetheless, the fact that other patterns of intonation were ignored and not accounted for does not delineate their existence. They were rather not accounted for because their occurrences did not significantly gain prominence in the intonation patterns of the selected bilingual educated speakers of English in Ebonyi State. Hence, there is no such extensive treatment. However, it is needful to point out that there were predominant patterns of low pitch accent ' $\mathrm{L}^{*}$ ', high pitch accent ' $\mathrm{H}^{*}$ ', bitonal pitch accent with low tone prominence followed by a high tone ' $\mathrm{L}^{*}+\mathrm{H}^{\prime}$, bitonal pitch accent with high tone prominence followed by a low tone ' $\mathrm{H}^{*+} \mathrm{L}$ ', and low phrase accent, low boundary tone ' $\mathrm{L}-\mathrm{L} \%$ ' with $36 \%, 20 \%, 17 \%, 24 \%$ and $4 \%$, respectively.

\subsection{Distribution of Patterns of Intonation}

The table below further shows the distribution of the patterns of intonation which were obtained from the utterances of the participants according to their performances in percentages.

Table 3. Distribution of patterns of intonation in percentage

\begin{tabular}{lllll}
\hline $\mathrm{S} / \mathrm{N}$ & Intonation Patterns & Frequency & Percentage & Expected Frequency \\
\hline 1 & $\mathrm{~L}^{*}$ & 124 & $36 \%$ & 90 \\
2 & $\mathrm{H}^{*}$ & 68 & $20 \%$ & 90 \\
53 & $\mathrm{~L}^{*+\mathrm{H}}$ & 58 & $17 \%$ & 135 \\
4 & $\mathrm{H}^{*}+\mathrm{L}$ & 81 & $24 \%$ & 45 \\
5 & $\mathrm{~L}-\mathrm{L} \%$ & 13 & $4 \%$ & - \\
& Total & 344 & & \\
\hline
\end{tabular}

Worthy of note is that the occurrence of $36 \%$ of the low pitch accent ' $\mathrm{L}^{*}$ ', in Table 3 on the distribution of patterns of intonation in percentages reveals its predominance among the other patterns realized by the participants. It further shows that majority of the bilingual educated speakers of English in Ebonyi State have no difficulty in its actualization. However, if at all there were any form of difficulty, then it could be seen in its inappropriateness in assignment which is clearly shown in Table 4 as seen in the words 'wind' and 'live' with $64 \%$ and $51 \%$ performances respectively, as appropriately assigned. This shows a mastery of falling tones among the participants. Strikingly, only $36 \%$ and $29 \%$ respectively realized the words as high pitch accent while $2 \%$ and $18 \%$ of the participants, in realizing the word 'live,' further gave prominence to fall-rise tone and rise-fall tone respectively. There was also a record of $20 \%$ use of high tones, $44 \%$ use of bitonal tones.

Table 4. Summary of intonation patterns of the participants

\begin{tabular}{|c|c|c|c|c|c|c|c|c|c|c|c|c|}
\hline \multirow{2}{*}{$\begin{array}{l}\mathbf{S} / \mathbf{N} \\
1\end{array}$} & \multirow{2}{*}{$\begin{array}{l}\text { Utterances/ } \\
\text { Expected Tones } \\
\text { Wind }\left(\mathrm{L}^{*}\right)\end{array}$} & \multicolumn{2}{|c|}{$\begin{array}{l}\text { Rising } \\
\text { Tones }\end{array}$} & \multicolumn{2}{|c|}{$\begin{array}{l}\text { Falling } \\
\text { Tones }\end{array}$} & \multicolumn{2}{|c|}{$\begin{array}{l}\text { Fall-Rise } \\
\text { Tones }\end{array}$} & \multicolumn{2}{|c|}{$\begin{array}{l}\text { Rise-Fall } \\
\text { Tones }\end{array}$} & \multicolumn{2}{|c|}{ Others } & \multirow{2}{*}{$\begin{array}{l}\text { Total } \\
\text { Partici-Pants } \\
45\end{array}$} \\
\hline & & 16 & $36 \%$ & 29 & $64 \%$ & - & - & - & - & - & - & \\
\hline 2 & Area $\left(\mathrm{H}^{*}\right)$ & 32 & $71 \%$ & 12 & $27 \%$ & 1 & $2 \%$ & - & - & - & - & 45 \\
\hline 3 & Live $\left(\mathrm{L}^{*}\right)$ & 13 & $29 \%$ & 23 & $51 \%$ & 1 & $2 \%$ & 8 & $18 \%$ & - & - & 45 \\
\hline 4 & Coast $\left(\mathrm{L}^{*+\mathrm{H}}\right)$ & 1 & $2 \%$ & 21 & $47 \%$ & 12 & $27 \%$ & 11 & $24 \%$ & 1 & $2 \%$ & 45 \\
\hline 5 & Sea $\left(H^{*}\right)$ & 6 & $13 \%$ & 20 & $44 \%$ & 9 & $20 \%$ & 10 & $22 \%$ & - & - & 45 \\
\hline 6 & $\operatorname{Wind}\left(\mathrm{L}^{*+\mathrm{H}}\right)$ & - & - & 9 & $20 \%$ & 12 & $27 \%$ & 24 & $53 \%$ & - & - & 45 \\
\hline 7 & $\begin{array}{l}\text { Obviously } \\
\left(\mathrm{H}^{*}+\mathrm{L}\right)\end{array}$ & - & - & - & - & 11 & $24 \%$ & 21 & $47 \%$ & 13 & $29 \%$ & 45 \\
\hline \multirow[t]{2}{*}{8} & Could $\left(\mathrm{L}^{*+\mathrm{H}}\right)$ & - & - & 20 & $44 \%$ & 13 & $29 \%$ & 12 & $27 \%$ & 1 & $2 \%$ & 45 \\
\hline & Total Tones & 68 & & 134 & & 59 & & 86 & & 15 & & \\
\hline
\end{tabular}

Furthermore, the $4 \%$ record of the Low pitch accent, low boundary tone L-L\%, which was not obtainable in that 
of the control, shows a replacement of tones. It further indicates its presence in the indigenous languages of the participants, little wonder it replaced other appropriate tones while it was not in any way obtainable in the control. However, a side by side placement of the actual performance and the expected performance of the participants indicates a high level of discrepancy between the control and the general performance of the educated bilingual speakers of English in Ebonyi State.

\subsection{Summary of Intonation Patterns of Participants}

With regard to assigning the rising tone, that is the high pitch accent, to utterances, it was observed that the participants were proficient in its assignment to the word 'area' with the record of $71 \%$ but less proficient in the word 'sea' which has a record of ' $13 \%$. An intent study of these two words reveals a significant difference in their respective performances. It is, therefore, not a costly assumption to say that the $71 \%$ appropriate assignment of the high pitch accent by the participants were based on the fact that the word 'area' is a bi-syllabic word and the interest was on the first. It was further observed that rather than assigning the appropriate intonation patterns to words like 'coast', 'sea', and 'could' which have their intonation patterns as $\mathrm{L}^{*}+\mathrm{H}, \mathrm{H}^{*}$ and $\mathrm{L}^{*}+\mathrm{H}$ respectively. $47 \%$ of the participants realized 'coast' as low pitch accent, that is the falling tone and $44 \%$ realized it with a low pitch accent. It is further in this vein that it can be deduced that the bitonal pitch accent with a low tone prominence, followed by a high tone $\left(\mathrm{L}^{*}+\mathrm{H}\right)$ and the high tone prominence, followed by a low tone $\left(\mathrm{H}^{*}+\mathrm{L}\right)$, even though significantly used among the bilingual educated speakers of English in Ebonyi State, have a level of inappropriateness in their assignment. This is seen as there is no significant difference between the $20 \%$ and $22 \%$ fall rise and rise fall respective realization of the word 'sea' which has its actual realization as a high tone accent ' $\mathrm{H}^{*}$ ' and $27 \%$ and $24 \%$ fall- rise and rise-fall respective realization of the word 'coast' which has its actual realization as a fall-rise, that is the bitonal pitch accent with a low tone prominence, followed by a high tone ' $\mathrm{L} * \mathrm{H}$ '.

However, these bitonal pitch accents were not observed to be scarce as there were yet educated speakers of English in the focus area who appropriately assigned this tone as in the case of $27 \%$ realization of fall rise in the words 'coast', and 'wind', and $29 \%$ realization in the word 'could'. It is further worthy to mention that $47 \%$ of the participants appropriately assigned the rise-fall tone to the syllable of interest in the word 'obviously'. In a bid to avoid a generalized conclusion, it becomes necessary that the description of the participants' performances in the use of patterns of intonation would be distributed according to their senatorial zones to evidently show the prevalent intonation patterns among the educated speakers of English in each zone.

\section{Conclusion}

This study investigated the intonation patterns of the bilingual educated speakers of English in Ebonyi State. The three Senatorial Zones were fully represented in the study as participants from each Local Government Area of the zones were randomly selected. With the use of ToBI, the Autosegmental-Metrical phonology was adopted for the analysis of the data. The findings reveal a low level of proficiency in the use and assignment of accurate patterns of intonation in the speeches of the bilingual educated speakers of English in Ebonyi State in spite of the recorded levels of educational attainment. It was observed that aside the widely known and commonly used intonation patterns of fall $\left(\mathrm{L}^{*}\right)$, rise $\left(\mathrm{H}^{*}\right)$, rise-fall $\left(\mathrm{H}^{*}+\mathrm{L}\right)$ and fall-rise $\left(\mathrm{L}^{*}+\mathrm{H}\right)$; the low pitch accent, low boundary tone (L-L\%) was also obtainable among the participants. However, the prevalent intonation patterns which were observed were $\mathrm{L}^{*}, \mathrm{H}^{*}, \mathrm{~L}^{*}+\mathrm{H}, \mathrm{H}^{*}+\mathrm{L}$ and $\mathrm{L}-\mathrm{L} \%$ with a record of preponderant use of unidirectional tones with a great inclination towards the use of the falling tones. It was further observed that the bilingual educated speakers of English in Ebonyi State have come to terms with the appropriate use and assignment of tones to weak syllables, bi-syllabic words and strong vowels in the initial position of a word.

Well observed and noted from the findings also, is what Okon (2001) described as restriction. Instances were seen as the participants replaced certain patterns of intonation with other tones which were more convenient for them and which could be assumed to be prevalent in their indigenous languages. It was in this vein that the bitonal pitch accents, which the study indicated were not scarce in the speeches of the participants, had a level of inappropriateness in their usages, hence, their less production in Nigerian English (Udofot, 2004). It is, therefore, interesting to mention that the analysis of the findings described the bilingual educated speakers of English in Ebonyi State as users of unidirectional intonation patterns especially that of the falling tone. These findings, however, imply that intonation should be practiced, using meaningful utterances in context. In a bid to account for effective communication among educated bilingual speakers of English, more time should be given to the development of this skill using meaningful utterances in context rather than the use of words or sentences in isolation.

Suffice it to say that in as much as the data was randomly collected from the three senatorial zones in Ebonyi 
State, the results of the study could be generalized to be obtainable in other parts of the country and beyond especially the speakers of English as a Second Language.

\section{Acknowledgements}

We sincerely acknowledge those whose works and ideas inspired this study. We equally thank the participants for agreeing to read the passage used for the study which led to the success of the research.

\section{References}

Akindele, J. (2015). Infrastructural and pedagogical challenges of spoken English learning in second language context: Need for information communication technology (ICT) driven approach. International Journal of Advanced Academic Research of Arts and Humanities, 1(3), 1-14.

Akinjobi, A., \& Oladipupo, R. (2010). Intonation and Attitude in Nigerian English. A Journal of Contemporary Research, 7(1), 159-167. https://doi.org/10.4314/lwati.v7i1.57478

Banjo, A. (1979). Towards a standard Nigerian spoken English. Abidjan: Actes du 8 congress de society linguistique de Africa Occidentials.

Ibrahim, S. \& Faleke, V. (2013). Pattern of intonation tunes in the marking of attitudes in Nigerian English. Journal of the Nigerian English Studies Association, 16(2), 171-187.

Okon, B. (2001). The Intonational structure of Nigerian English (PhD Thesis. Department of English. University of Ibadan).

Roach, P. (2010). English Phonetics and Phonology: A practical course (4th ed.). Cambridge: Cambridge University Press.

Suciu, G. (2016). Intonation- The music of everyday speech-and its impact on successful communication. Convergent Discourse: Exploring the Context of Communication, 17(4), 180-184.

Sunday, A. (2010). The Supra-segmentals of bilingual Nigerian adult aphasias. SKASE Journal of Theoretical Linguistics, 7(2), 39-66.

Udofot, I. (2004). Varieties of spoken Nigerian English. In V. Awonusi, \& E. Babalola (Eds.), The domestication of English in Nigeria (pp. 93-113). Lagos: University of Lagos Press.

Weinreich, U. (1968). Languages in Contact: Findings and problems. New York: Mouton Publishers.

\section{Appendix}

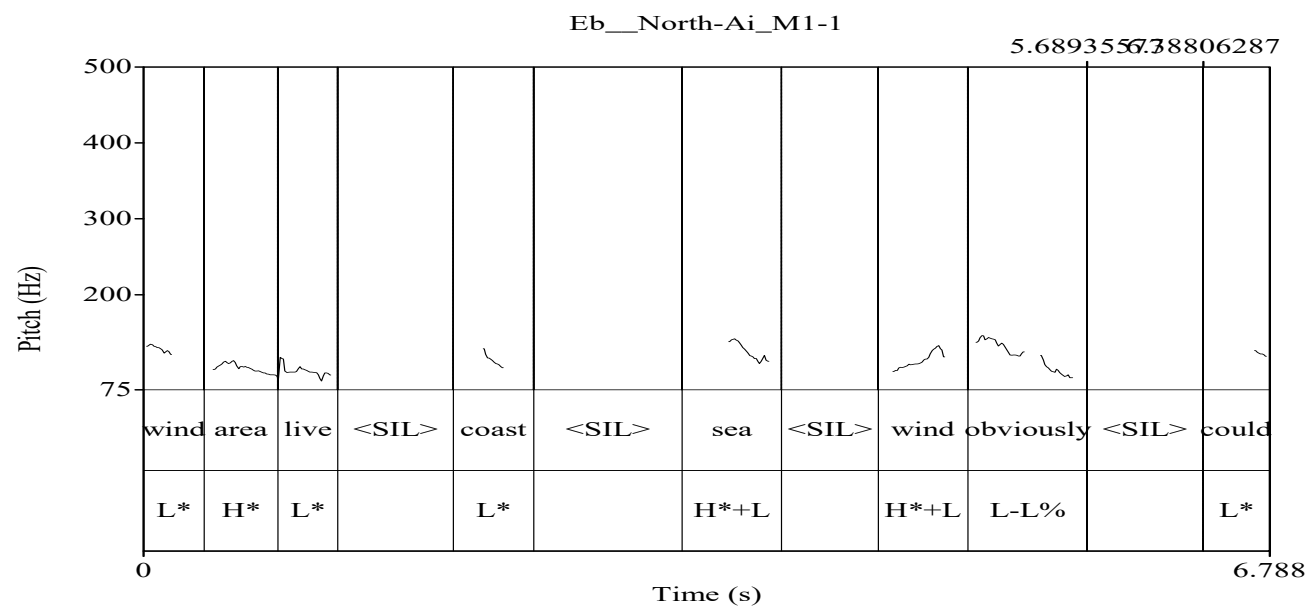

Figure 1. Ebonyi North, Abakiliki LGA 


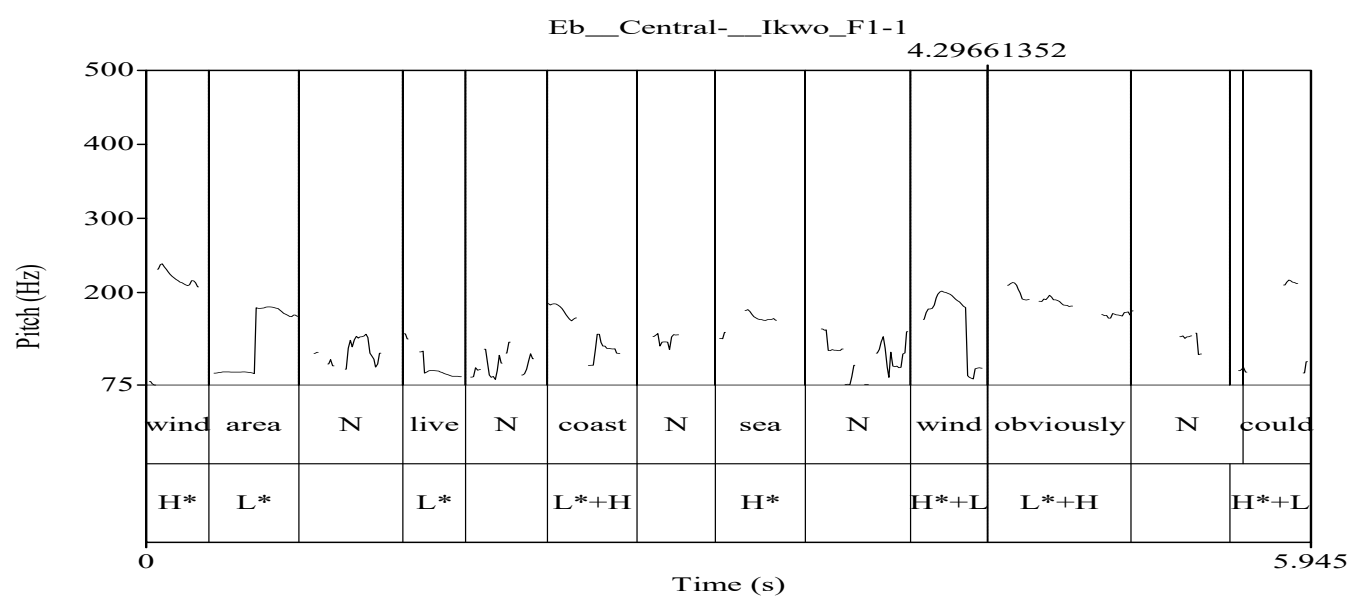

Figure 2. Ebonyi Central, Ikwo LGA

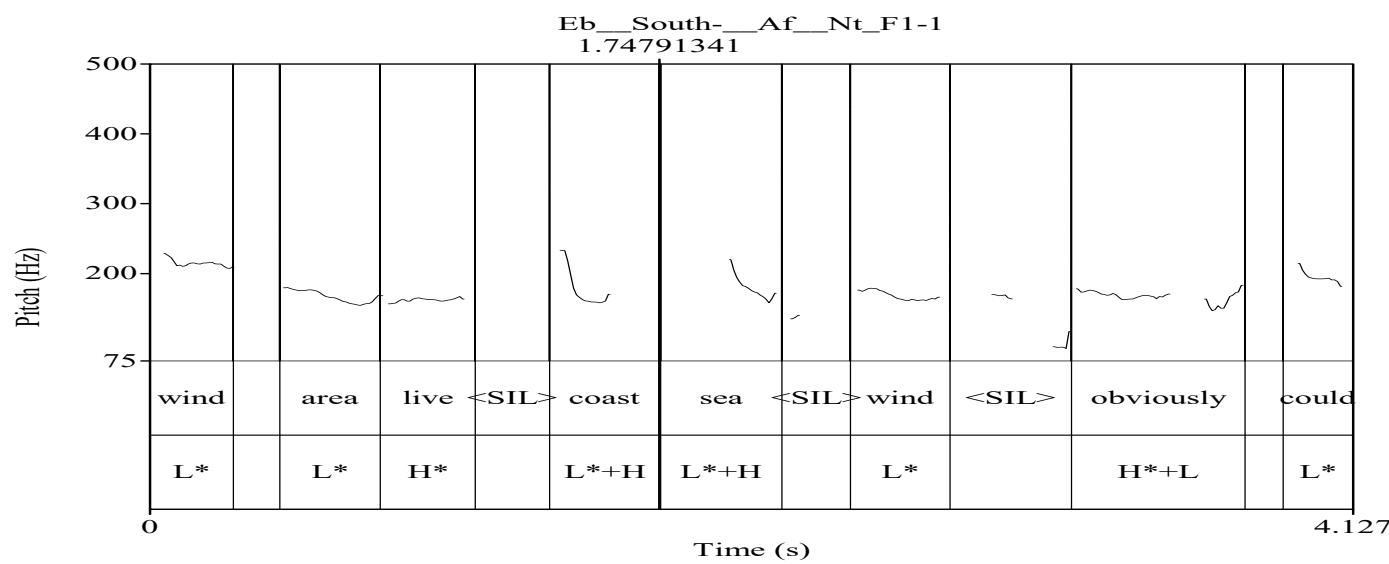

Figure 3. Ebonyi South, Afikpo LGA

\section{Copyrights}

Copyright for this article is retained by the author(s), with first publication rights granted to the journal.

This is an open-access article distributed under the terms and conditions of the Creative Commons Attribution license (http://creativecommons.org/licenses/by/4.0/). 